Research Article

\title{
Clinico-histopathological analysis of malignant soft tissue tumors
}

\author{
Deepak MB ${ }^{1}$, Suchitha $S^{2}$, Manjunath $G^{3}$, Ira Bharadwaj ${ }^{4}$ \\ ${ }^{1}$ Dr Deepak MB, Assistant Professor, Department of Pathology, Karuna Medical College, Chittur, Kerala, ${ }^{2}$ Dr Suchitha \\ S, Associate Professor, Department of Pathology, JSS Medical College, Mysore, Karnataka, ${ }^{3}$ Dr Manjunath GV, \\ Professor and HOD, Department of Pathology, JSS Medical College, Mysore, Karnataka, ${ }^{4}$ Dr Ira Bharadwaj, Professor \\ and HOD, Department of Pathology, Karuna Medical College, Chittur, Kerala, India.
}

Address for Correspondence: Dr Deepak MB, Email: deepakmb.skt@ gmail.com

\begin{abstract}
Background: Aim of the study was to analyze the histopathological findings in various malignant soft tissue tumors and to study its incidence in relation to age, gender and anatomical site. Material and Method: Total of 250 cases of soft tissue lesions were analyzed retrospectively and prospectively in a period 2.5 years during June 2009 to Dec 2011 . In addition to routine Haematoxylin and Eosin stained sections of all the specimens, special stains with immunohistochemical markers were done wherever necessary. Result: Of 250 lesions analyzed, 30 (12\%) were soft tissue sarcomas. They were encountered slightly more in males than females. Majority of the malignant tumors occurred in fifth decade (20\%). The most common site of occurrence was trunk (40\%). Dermatofibrosarcoma protuberans was the most common malignant soft tissue tumor ( 7 cases, 23.3\%). IHC studies were performed in 13 tumors for further confirmation. On gross examination $18(60 \%)$ measured more than $5 \mathrm{cms}$. Majority of soft tissue sarcomas were grade III accounting for $18(60 \%)$ cases. Conclusion: Even though soft tissue sarcomas are rare, they are life threatening posing a significant diagnostic and therapeutic challenge and must be diagnosed early for better management. Immunohistochemistry plays a vital role in precise diagnosis and sub categorization. Grading is the most important prognostic factor and the best indicator of metastatic risk. Therefore it should be part of the pathology report for treatment stratification.
\end{abstract}

Key words: Soft tissue tumors; Malignant tumors; Bednar tumor; Calcifying synovial sarcoma; Grading.

\section{Introduction}

Soft tissue is defined as non-epithelial extra skeletal tissue of the body exclusive of the reticuloendothelial system, glial and supportive tissue of various parenchymal organs. It is composed of connective tissue, adipose tissue, skeletal muscle, smooth muscle, blood vessels, lymphatics and peripheral nervous system[1].

The term "malignant" indicates that there is moderate to high probability that the tumor will spread beyond the site where it initially develops. These cells can spread by travel through the blood stream or by travel through lymph vessels. The most common sites where malignant soft tissue tumors spread are the lungs and the liver [2]. Malignant soft tissue tumors are classified as "sarcomas." They arise nearly everywhere in the

Manuscript received: $4^{\text {th }}$ October 2016

Reviewed: $15^{\text {th }}$ October 2016

Author Corrected: $25^{\text {th }}$ October 2016

Accepted for Publication: $9^{\text {th }}$ November 2016 body, the most important locations being the extremities, trunk, abdominal cavity and head \& neck region [3].

Overall, the age-adjusted annual incidence of soft tissue sarcomas ranges from 15 to 35 per 1 million populations. The incidence increases steadily with age and is slightly higher in men than in women. Malignant soft tissue tumors constitute less than $1 \%$ of all cancers and occur twice as often as primary bone sarcomas $[4,5]$. Soft tissue sarcomas are the fourth most common malignancy in children, after hematopoietic neoplasm, neural tumor and Wilms tumor. It accounts for $15 \%$ of all childhood cancers [6].

Soft tissue sarcomas may occur anywhere but three fourths are located in the extremities (most common in thigh) and $10 \%$ each in the trunk wall and retroperitoneum [7]. The different types of soft tissue 
tumors have distinct age distributions. Rhabdomyosarcoma is seen more frequently in children and young adults. Synovial sarcoma arises in young adults. Malignant fibrous histiocytoma and liposarcoma generally occur in older adults [5].

The degree of differentiation is a reliable indicator of future behavior but sometimes differentiation is misleading. Certain sarcomas may metastasize widely despite of their relative high degree of differentiation while on the other hand tends to pursue an aggressive clinical course that one would expect from their immature histological appearance $[4,8]$.

The recurrence rate of primary soft tissue sarcomas after treatment is approximately 40 to $60 \%$. Factors accounting for local recurrence are tumor size, tumor differentiation, histological grade, and type of local treatment received [9]. It is critical to recognize immunohistochemistry as an adjunctive technique, which does not supercede or replace the traditional morphologic diagnosis on haematoxylin and eosin stained sections [10].

\section{Objectives}

1. To study the occurrence of soft tissue tumors in relation to age, gender and anatomical site.
2. To study the histopathological findings in the malignant soft tissue tumors.

3. To grade malignant soft tissue tumors for treatment stratification.

\section{Materials and Methods}

The soft tissue tumors received at the histopathology unit of Department of Pathology, JSS Hospital, Mysore, were studied for a period of two and a half years. Clinical details of all the cases were collected in pretested proforma meeting the objectives of the study. A detailed gross examination of the soft tissue specimen was performed to record the tumor size, shape, colour, consistency and distance from the deep resected margins.

The specimens were preserved in $10 \%$ formalin and allowed to fix for $24 \mathrm{hrs}$. The haematoxylin and eosin stained sections of all the specimens obtained by routine processing and paraffin embedding were studied to evaluate histopathological features. Special stains such as periodic acid Schiff (PAS), reticulin along with immunohistochemical markers were done, wherever necessary. The classification adopted for the present study is based on the WHO classification of soft tissue tumors (2002) [11].

\section{Results}

During the study period, among 250 cases studied 30 were diagnosed as soft tissue sarcomas. Among them 18 cases were more than $5 \mathrm{cms}$ in size.

Tumors of fibroblastic/myofibroblastic differentiation accounted for the majority of malignant soft tissue tumors (26.7\%), which is summarized in table 1 .

Table-1: Distribution of malignant soft tissue tumors.

\begin{tabular}{|c|c|c|c|}
\hline \multirow{2}{*}{ Sl.No. } & \multirow{2}{*}{ Tumors } & \multicolumn{2}{|c|}{ Malignant } \\
\cline { 2 - 4 } & Fibroblastic/myofibroblastic & No. of cases (n=30) & 26.7 \\
\hline 1. & Fibrohistiocytic & 6 & 20 \\
\hline 2. & Smooth muscle & 1 & 3.3 \\
\hline 3. & Skeletal muscle & 5 & 16.7 \\
\hline 4. & Neural & 1 & 3.3 \\
\hline 5. & Vascular & 1 & 3.3 \\
\hline 6. & Chondro-osseous & 5 & 16.7 \\
\hline 7. & Uncertain differentiation & 3 & 10 \\
\hline
\end{tabular}

Malignant soft tissue tumors were encountered slightly more in males than females with male to female ratio of $1.1: 1$. (Table 2) 
Research Article

Table-2: Gender distribution of malignant soft tissue tumors.

\begin{tabular}{|c|c|c|c|c|c|c|}
\hline Sl.No. & Tumors & Males & $\mathbf{\%}$ & Females & \% & Total \\
\hline 1 & Fibroblastic/ myofibroblastic & 3 & 10 & 5 & 16.7 & 8 \\
\hline 2 & Fibrohistiocytic & 2 & 6.7 & 4 & 13.3 & 6 \\
\hline 3 & Smooth muscle & - & - & 1 & 3.3 & 1 \\
\hline 4 & Skeletal muscle & 3 & 10 & 2 & 6.7 & 5 \\
\hline 5 & Neural & 3 & 10 & - & - & 3 \\
\hline 6 & Vascular & - & - & 1 & 3.3 & 1 \\
\hline 7 & Chondro-osseous & 1 & 3.3 & - & - & 1 \\
\hline 8 & Uncertain differentiation & 4 & 13.3 & 1 & 3.3 & 5 \\
\hline & Total & $\mathbf{1 6}$ & $\mathbf{5 3 . 3}$ & $\mathbf{1 4}$ & $\mathbf{4 6 . 7}$ & $\mathbf{3 0}$ \\
\hline
\end{tabular}

The youngest patient in the present study was 4 months while the oldest was 70 years old. Majority of the malignant tumors occurred in the fifth decade. (Table 3)

Table-3: Age distribution of malignant soft tissue tumors.

\begin{tabular}{|c|c|c|c|c|c|c|c|c|c|c|}
\hline SI.No. & Tumors type & $\mathbf{0 - 9}$ & $\mathbf{1 0 - 1 9}$ & $\mathbf{2 0 - 2 9}$ & $\mathbf{3 0 - 3 9}$ & $\mathbf{4 0 - 4 9}$ & $\mathbf{5 0 - 5 9}$ & $\mathbf{6 0 - 6 9}$ & $\mathbf{7 0 - 7 9}$ & $\mathbf{8 0 - 8 9}$ \\
\hline 1 & $\begin{array}{c}\text { Fibroblastic/ } \\
\text { myofibroblastic }\end{array}$ & - & - & - & 2 & 3 & 1 & 1 & 1 & - \\
\hline 2 & Fibrohistiocytic & - & - & - & - & 1 & 2 & 2 & 1 & - \\
\hline 3 & Smooth muscle & - & - & - & 1 & - & - & - & - & - \\
\hline 4 & Skeletal muscle & 3 & - & 1 & 1 & - & - & - & - & - \\
\hline 5 & Neural & - & - & 1 & - & - & - & 1 & 1 & - \\
\hline 6. & Vascular & - & - & - & - & - & - & 1 & - & - \\
\hline 7. & Chondro-osseous & - & 1 & - & - & - & - & - & - & - \\
\hline 8. & $\begin{array}{c}\text { Uncertain } \\
\text { differentiation }\end{array}$ & - & - & 3 & 1 & 1 & - & - & - & - \\
\hline & Total & $\mathbf{3}$ & $\mathbf{1}$ & $\mathbf{5}$ & $\mathbf{4}$ & $\mathbf{6}$ & $\mathbf{3}$ & $\mathbf{5}$ & $\mathbf{3}$ & - \\
\hline
\end{tabular}

Malignant soft tissue tumors showed a marked predilection for trunk followed by lower extremity. (Table 4, graph 1)

Table-4: Site distribution of malignant soft tissue tumors

\begin{tabular}{|c|c|c|c|c|c|c|c|}
\hline \multirow{3}{*}{ Sl.No. } & \multirow{3}{*}{ Tumor type } & \multicolumn{4}{|c|}{ Extremities } & \multirow{3}{*}{ Trunk } & \multirow{3}{*}{$\begin{array}{c}\text { Head } \\
\text { and neck }\end{array}$} \\
\hline & & \multicolumn{2}{|c|}{ Upper } & \multicolumn{2}{|c|}{ Lower } & & \\
\hline & & Proximal & Distal & Proximal & Distal & & \\
\hline 1. & Fibroblastic/myofibroblastic & 4 & - & - & - & 5 & - \\
\hline 2. & Fibrohistiocytic & - & - & 3 & - & 1 & - \\
\hline 3. & Smooth muscle & - & - & - & - & 1 & - \\
\hline 4. & Skeletal muscle & - & - & - & - & 4 & 1 \\
\hline 5. & Neural & 1 & 1 & 1 & - & - & - \\
\hline 6. & Vascular & - & - & - & - & 1 & - \\
\hline 7. & Chondro-osseous & - & - & - & - & - & - \\
\hline 8. & Uncertain differentiation & - & 2 & 1 & 4 & - & - \\
\hline & Total & 5 & 3 & 5 & 4 & 12 & 1 \\
\hline
\end{tabular}

Five cases of undifferentiated pleomorphic sarcoma were encountered in the present study. Majority of the tumors occurred in thigh region with female preponderance. One case of undifferentiated pleomorphic sarcoma with giant cells was seen in 60 years female patient presenting as mass in the back. (Table 5a) 
Research Article

Table-5 (a): Age, gender, site and histological subtypes of fibrohistiocytic tumors.

\begin{tabular}{|c|c|c|c|c|c|}
\hline Sl.No. & Histological type & $\begin{array}{c}\text { No. of cases (\% of } \\
\text { tumors) malignant }\end{array}$ & $\begin{array}{c}\text { Age in years } \\
\text { (Range) }\end{array}$ & $\begin{array}{c}\text { Sex } \\
\text { M/F }\end{array}$ & Common site \\
\hline 1. & $\begin{array}{c}\text { Undifferentiated pleomorphic } \\
\text { sarcoma }\end{array}$ & $5(16.7 \%$ & $50-70$ & $2 / 3$ & $\begin{array}{c}\text { Extremity } \\
\text { (thigh) }\end{array}$ \\
\hline 2. & $\begin{array}{c}\text { Undifferentiated pleomorphic } \\
\text { sarcoma with giant cells }\end{array}$ & $1(3.3 \%)$ & 60 & $--/ 1$ & Trunk (back) \\
\hline & Total & $\mathbf{6 ( 2 0 \% )}$ & $\mathbf{2 / 4}$ & $\mathbf{( 1 : 2 )}$ \\
\hline
\end{tabular}

Microscopically pleomorphic sarcoma showed sheets, fascicles and whorls of spindle cells with moderate to severe degree of nuclear pleomorphism. Areas of necrosis and numerous mitoses were noted. Tumor giant cells were also seen.

Only one case of adult fibrosarcoma was encountered in the present study. Dermatofibrosarcoma protuberans was the most common malignant soft tissue tumor (seven cases, 23.3\%) of which one was pigmented type. DFP showed slight female predilection with a male to female ratio of 1:1.7 and most common site being extremity (shoulder region), which is summarized in table $5(\mathrm{~b})$.

Table-5 (b): Age, gender, site and histological types of Fibroblastic/Myofibroblastic tumors

\begin{tabular}{|c|c|c|c|c|c|}
\hline SI.No. & Histological type & $\begin{array}{c}\text { No. of cases (\% of } \\
\text { tumors) malignant }\end{array}$ & $\begin{array}{c}\text { Age in years } \\
\text { (Range) }\end{array}$ & $\begin{array}{c}\text { Sex } \\
\mathbf{M} / \mathbf{F}\end{array}$ & Common site \\
\hline 1. & Adult fibrosarcoma & $1(3.3 \%)$ & 70 & $--/ 1$ & Extremity \\
\hline 2. & $\begin{array}{c}\text { Dermatofibrosarcoma } \\
\text { protuberans }\end{array}$ & $7(23.3 \%)$ & $35-62$ & $3 / 4$ & Extremity \\
\hline & Total & $8(26.6 \%)$ & & $3 / 51: 1.7$ & \\
\hline
\end{tabular}

Microscopically adult fibrosarcoma was characterized by sheets and fascicles of spindle cells with moderate eosinophilic cytoplasm and nuclear atypia. At few foci spindle cells were arranged in characteristic herringbone pattern. Pigmented DFSP showed tumor cells arranged in storiform pattern with scattered pigmented cells. Spindle cells showed mild nuclear pleomorphism. [Figure 1a, 1b]

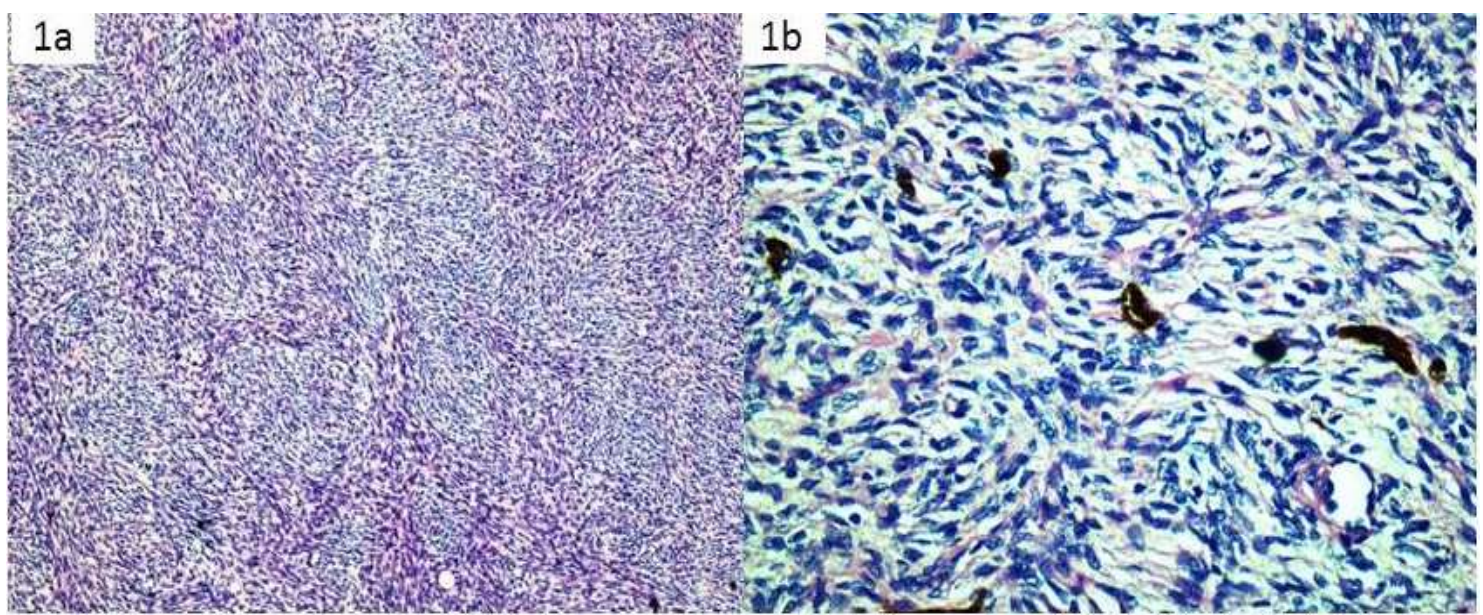

Fig la: Bednar tumor (Pigmented DFSP) - Tumor cells arranged in storiform pattern (H\& E, 10x); Fig lb: Spindle cells showing mild pleomorphism with dendritic pigmented cells $(\mathrm{H} \& \mathrm{E}, 40 \mathrm{x})$.

There was one case of leiomyosarcoma in a 45 year old female presenting as retroperitoneal mass. Microscopically the tumor showed nodules, bundles and intersecting fascicles of spindle cells. The tumor cell nuclei were characteristically elongated and blunt-ended with nuclear hyperchromatism and pleomorphism. Areas of myxoid change and hyalinization were seen. 
One case of angiosarcoma was encountered in a 68 year old female presenting as pigmented lesion over sacrum. Microscopically the tumor was seen in the dermis with wide areas of hemorrhage and necrosis. Tumor cells had pleomorphic vesicular nuclei, dissecting collagen bundles.

Only one case of mesenchymal chondrosarcoma was seen in a 19 year-old male patient presenting as calf swelling. Microscopically the tumor was characterized by islands of well-differentiated cartilage surrounded by sheets of small, undifferentiated tumor cells. The undifferentiated cells had ovoid or elongated hyperchromatic nuclei and scanty, poorly outlined cytoplasm arranged in sheets, small aggregates and in a hemangiopericytoma-like pattern.

Five cases of rhabdomyosarcomas were encountered in the present study. Three of them were embryonal rhabdomyosarcomas with female predilection and common site being cervix. There were two cases of alveolar rhabdomyosarcomas both of which occurred in the first decade of life in male patients presenting as antrachoanal polyp and retroperitoneal mass. (Table 5c)

Table-5 (c): Skeletal muscle tumors

\begin{tabular}{|c|c|c|c|c|c|}
\hline Sl. No. & Histological type & $\begin{array}{c}\text { No. of cases (\% } \\
\text { of malignant } \\
\text { tumors) }\end{array}$ & $\begin{array}{c}\text { Age in years } \\
\text { (Range) }\end{array}$ & Sex M/F & Common site \\
\hline 1. & Embryonal rhabdomyosarcoma & $3(10 \%)$ & $<1-26$ & $1 / 2$ & Cervix \\
\hline 2. & Alveolar rhabdomyosarcoma & $2(6.6 \%)$ & $2-4$ & $2 /--$ & $\begin{array}{c}\text { Head and neck, } \\
\text { trunk }\end{array}$ \\
\hline & Total & $\mathbf{5 ( 1 6 . 6 \% )}$ & & $\begin{array}{c}\mathbf{3 / 2} \\
(\mathbf{1 . 5} 7)\end{array}$ & \\
\hline
\end{tabular}

Microscopically embryonal rhabdomyosarcomas were characterized by immature oval to spindle cells, with scattered foci of rhabdomyoblasts in a myxoid matrix. Botryoid variant showed tumor cells tightly abutting epithelial surface forming a cambium layer. Alveolar rhabdomyosarcomas were characterized by hypocellular and hypercellular areas with scattered giant cells. Tumor cells were round to oval and multinucleated giant cells had peripherally placed "Wreath-like" nuclei [Fig 2].

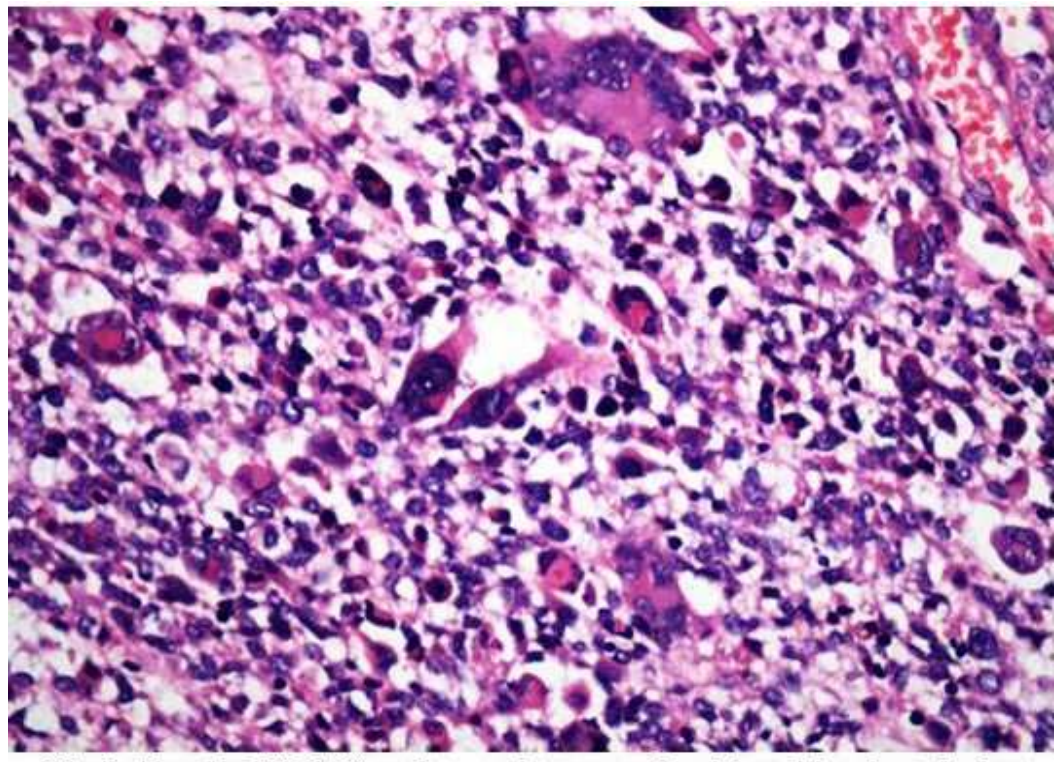

Fig 2: Alveolar RMS-Round to oval tumor cells with multinucleated giant cells having peripherally placed "wreath-like" nuclei (H \& E,40x).

There were five cases of sarcoma of uncertain differentiation occurring in third, fourth and fifth decade over the extremities. Out of five cases, two cases were synovial sarcomas with equal sex predilection and one each was epitheloid sarcoma, clear cell sarcoma and PNET/extra skeletal Ewing sarcoma (Table 5d). 
Research Article

Table-5 (d): Tumors of uncertain differentiation.

\begin{tabular}{|c|c|c|c|c|c|}
\hline Sl. No. & Histological type & $\begin{array}{c}\text { No. of cases (\% of } \\
\text { malignant tumors) }\end{array}$ & $\begin{array}{c}\text { Age in years } \\
\text { (Range) }\end{array}$ & $\begin{array}{c}\text { Sex } \\
\text { M/F }\end{array}$ & Common site \\
\hline 1. & Synovial sarcoma & $2(6.7 \%)$ & $25-45$ & $1 / 1$ & Extremity \\
\hline 2. & Epitheloid sarcoma & $1(3.3 \%)$ & 38 & $1 /--$ & Forearm \\
\hline 3. & Clear cell sarcoma & $1(3.3 \%)$ & 25 & $1 /--$ & Leg \\
\hline 4. & PNET/Extraskeletal Ewings & $1(3.3 \%)$ & 25 & $1 /--$ & Foot \\
\hline & Total & $\mathbf{5 ( 1 6 . 6 \% )}$ & & $\begin{array}{c}\mathbf{4} / \mathbf{1} \\
\mathbf{( 4 : 1 )}\end{array}$ \\
\hline
\end{tabular}

Microscopically biphasic synovial sarcoma had epithelial and spindle cell components, in varying proportions. The epithelial cells were arranged in glandular patterns having ovoid nuclei and abundant cytoplasm. The spindle cells were uniform and relatively small, with ovoid, pale-staining nuclei and inconspicuous nucleoli.

Calcifying synovial sarcoma was grossly characterized by well circumscribed grey white mass with microscopy revealing foci of calcifications amidst dense fibrous tissue containing pleomorphic spindle cells [Fig 3].

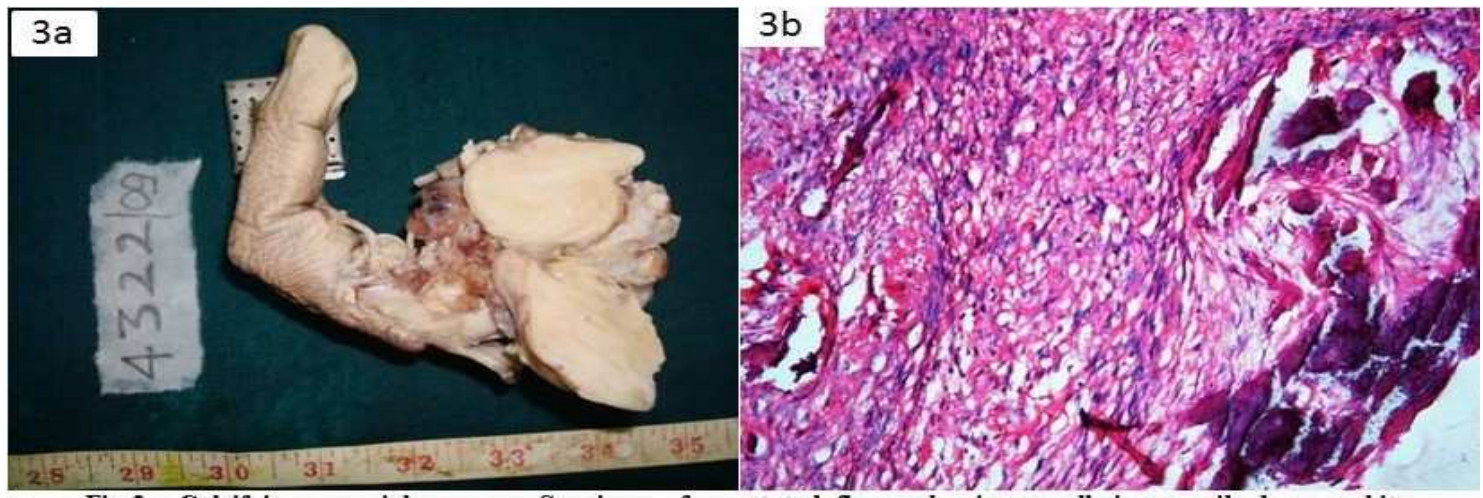

Fig 3a: Calcifying synovial sarcoma- Specimen of amputated finger showing a well circumscribed grey-white tumor on cut-section; Fig 3b: Pleomorphic spindle cells with areas of calcification (H \& E, 20x).

Epitheloid sarcoma showed nodules of tumor cells separated by thick fibrous septae. Tumor cells had moderate eosinophilic cytoplasm, vesicular nuclei and prominent nucleoli. Clear cell sarcoma showed nests of tumor cells separated by fibrous septae. Individual tumor cells had scanty eosinophilic cytoplasm, vesicular nuclei and prominent nucleoli. Extraskeletal Ewing sarcoma was characterized by uniform round to oval tumor cells separated by hyalinized stroma. Individual tumor cells had clear cytoplasm and vesicular nuclei.

Three cases (10\%) of MPNST were encountered in the present study, all of which occurred over extremities among male patients aged between 25 to 70 years. Grossly well circumscribed irregular myxoid grey-white mass was noted on cut section. Microscopically they were characterized by tumor cells arranged in cords and singles in a myxoid background. Individual cells were short and fusiform and showed moderate nuclear atypia [Figure 4].

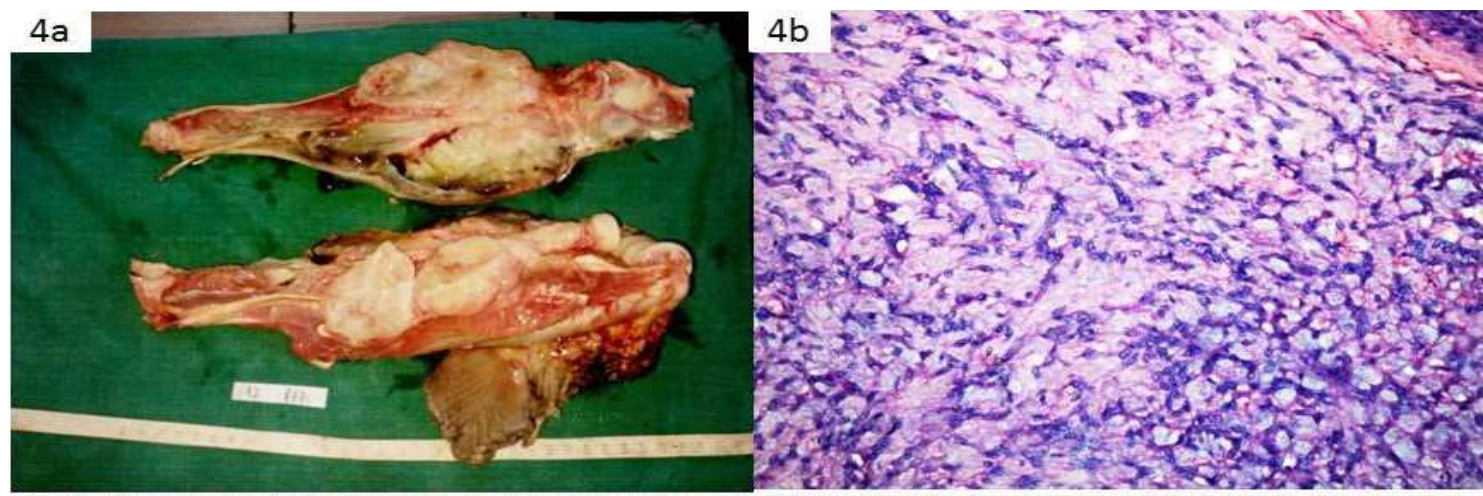

Fig 4a: MPNST- Two well circumscribed grey-shite lesions with areas of myxoid change on cut-section; Fig 4b: Tumor cells arranged in cords and singles in a myxoid background (H \& E, 20x). 
Soft Tissue Tumor Grading- Grading adopted for the present study was based on Federation Nationale des centres de Lutte Centre Le Cancer (FNCLCC) system, a 3-tier system mainly based on histologic type and subtype, tumor necrosis and mitotic activity. ${ }^{12}$ Mitotic count was done away from necrotic, hypocellular and ulcerated areas. Necrosis previous to surgery and ulceration were not taken into account. Haemorrhagic changes or hyalinization were not considered either.

Among 30 malignant soft tissue tumors diagnosed, 9 were Grade I tumors, 3 were Grade II tumors and 18 were Grade III tumors.

IHC studies were performed in 13 malignant tumors for further confirmation. In three tumors initial diagnosis had to be revised based on the IHC positivity. These tumors included infantile fibrosarcoma, Ewings / Primitive neuroectodermal tumor (PNET) and intermediate grade STT which were respectively revised into embryonal rhabdomysarcoma (desmin, $\mathrm{MyoD}_{1}$ and Myogenin positive), clear cell sarcoma (s-100, vimentin positive) and dermatofibrosarcoma protuberans (CD34, SMA positive), which is summarized in table 6.

Table-6: IHC studies of malignant soft tissue tumors.

\begin{tabular}{|c|c|c|c|c|}
\hline Sl. No. & Age/Sex & Site & HPD & IHC \\
\hline 1. & $25 \mathrm{Y} / \mathrm{M}$ & Left thigh mass & MPNST & S-100, +ve \\
\hline 2. & $38 \mathrm{Y} / \mathrm{M}$ & Forearm swelling & Epitheloid sarcoma & $\begin{array}{c}\text { EMA, CD34+ve. } \\
\text { S-100 sparsely +ve. }\end{array}$ \\
\hline 3. & $40 \mathrm{Y} / \mathrm{M}$ & Retroperitoneal mass & Infantile fibrosarcoma & $\begin{array}{c}\text { Desmin, MyoD1, myogenin+ve. } \\
\text { Revised diagnosis-Embryonal } \\
\text { RMS }\end{array}$ \\
\hline 4. & $60 \mathrm{Y} / \mathrm{M}$ & Left arm mass & MPNST & S-100+ve \\
\hline 5. & $25 \mathrm{Y} / \mathrm{M}$ & $\begin{array}{l}\text { Left hand -recurrent } \\
\text { swelling }\end{array}$ & Calcifying synovial sarcoma & EMA, Mic-2 +ve \\
\hline 6. & $25 \mathrm{Y} / \mathrm{M}$ & Mass upper $1 / 3$ leg & Ewings/PNET & $\begin{array}{l}\text { S-100, vimentin+ve. Revised } \\
\text { diagnosis-Clear cell sarcoma }\end{array}$ \\
\hline 7. & $70 \mathrm{Y} / \mathrm{M}$ & Left forearm mass & MPNST & S-100+ve \\
\hline 8. & $26 \mathrm{Y} / \mathrm{M}$ & Cervical polyp & Embryonal RMS & Desmin +ve \\
\hline 9. & $19 \mathrm{Y} / \mathrm{M}$ & Left calf mass & Mesenchymalchondrosarcoma & Mic2 +ve. SMA focally +ve \\
\hline 10. & $50 \mathrm{Y} / \mathrm{M}$ & $\begin{array}{l}\text { Fungating lesion over } \\
\text { the chest }\end{array}$ & $\begin{array}{l}\text { Soft tissue sarcoma } \\
\text { (intermediate grade) }\end{array}$ & $\begin{array}{c}\text { CD34, SMA+ve. } \\
\text { Revised diagnosis- } \\
\text { Dermatofibrosarcoma } \\
\text { protuberans }\end{array}$ \\
\hline 11. & $25 \mathrm{Y} / \mathrm{M}$ & Left foot lesion & Ewings/PNET & FLI-1, Mic-2 +ve \\
\hline 12. & $68 \mathrm{Y} / \mathrm{F}$ & $\begin{array}{l}\text { Pigmented lesion over } \\
\text { sacrum }\end{array}$ & Angiosarcoma & CD31+ve \\
\hline 13. & $2 \mathrm{Y} / \mathrm{M}$ & Antrachoanal polyp & Alveolar rhabdomyosarcoma & Desmin, MyoD1, myogenin + \\
\hline
\end{tabular}

Patients with malignant soft tissue tumors more than $5 \mathrm{~cm}$ in size underwent multimodal therapy consisting of surgery with chemotherapy, radiation therapy or both. Tumors with size less than $5 \mathrm{~cm}$ were treated by complete excision with negative margins. Two cases were assigned to amputation at or above the joint proximal to the tumor.

Lifetime follow up was advised for all patients to monitor for local recurrence and metastasis.

\section{Discussion}

In the present study the most common histological type was fibroblastic/myofibroblastic tumors. This is in contrast to Jenson OM and Kransdorf MJ where the most common histological type was fibrohistiocytic tumors. (Table 7) 
Research Article

Table-7: Comparative analysis of relative distribution of various malignant tumors.

\begin{tabular}{|c|c|c|c|}
\hline Tumor type & $\begin{array}{c}\text { Jensen OM } \\
(\mathbf{\%}) \\
(\mathbf{n = 2 4 8})\end{array}$ & $\begin{array}{c}\text { Kransdorf MJ }{ }^{\mathbf{1 4}} \\
(\mathbf{\%}) \\
(\mathbf{n = 1 2 3 7 0})\end{array}$ & $\begin{array}{c}\text { Present study (\%) } \\
(\mathbf{n}=\mathbf{3 0})\end{array}$ \\
\hline Fibroblastic/Myofibroblastic & 19.4 & 11.5 & 26.7 \\
\hline Fibrohistiocytic & 40.3 & 25.7 & 20 \\
\hline Smooth muscle & 6.9 & 8.4 & 3.3 \\
\hline Skeletal muscle & 6.9 & 1.9 & 16.7 \\
\hline Neural & - & 6.3 & 3.3 \\
\hline Vascular & - & 4.3 & 3.3 \\
\hline Chondro-osseous & 5.6 & 2.7 & 16.7 \\
\hline
\end{tabular}

The age distribution of various malignant soft tissue tumors ranged from 4 months to 89 years. The average age in the case of malignant tumors was 43.6 years, which is comparable to the studies of Jensen OM.

In case of malignant tumors there were 16 males and 14 females with a male to female ratio of 1.1:1 which is comparable to the study of Jensen OM [13].

Malignant soft tissue tumors were observed to have a greater predilection for trunk (40\%) followed by lower extremity, in contrast to the study of Kransdorf MJ where the common site was lower extremity [14].

Eight cases of malignant fibrous tumors were encountered in the present study occurring over the extremity with female preponderance. This is in contrast to the study of Kransdorf MJ where the common site was trunk with slight male preponderance [14].

There were six cases of pleomorphic sarcoma with female preponderance, the most common site being the lower extremity. This is in contrast to the study of Kransdorf MJ where pleomorphic MFH was the most common variant with male preponderance [14].

Five cases of rhabdomyosarcomas were encountered in the present study the common site being cervix with male preponderance. This is in contrast to the study of Kransdorf MJ wherein rhabdomyosarcomas were more common in head and neck with male predilection [14].

There were five cases of malignant tumors of uncertain differentiation occurring commonly in extremities with male predilection, which is similar to the study of Kransdorf MJ [14].

On gross examination, $60 \%$ malignant tumors measured more than $5 \mathrm{~cm}$ whereas Jensen OM reported $75 \%$ for malignant tumors [13].

\section{Conclusion}

Even though malignant mesenchymal neoplasms amount to less than $1 \%$ of the overall human burden of malignant tumors, they are life threatening and may pose a significant diagnostic and therapeutic challenge. Even though soft tissue sarcomas are rare and usually present as painless mass, they must be diagnosed early for better management. The diagnosis and management of soft tissue tumors require a team perspective consisting of clinical, radiological and pathological correlation. A careful gross examination of the specimen and adequate sampling of the tumor is essential. Special stains and IHC are helpful in addition to the routine haematoxylin and eosin for the proper diagnosis of STT's.

Undifferentiated malignant neoplasms are a daunting diagnostic problem for anatomical pathologists, calling for a tour de force in morphological skill and clinicpathological correlation.

Grading is the best prognostic indicator of malignant soft tissue tumors and predictor of metastasis outcome. 
It should be part of the pathologic report. Grading should be adapted to the modern management of patients complemented by molecular parameters and genetic analysis.

Funding: Nil, Conflict of interest: None initiated, Permission from IRB: Yes

\section{References}

1. Myhre-Jensen $\mathrm{O}$, Kaae $\mathrm{S}$, Madsen $\mathrm{EH}$, et al. Histopathological staging in soft tissue tumours in relation to in 261 surgically treated patients. Acta Pathol Microbiol Immunol Scand A. 1983 Mar; 91 (2): 145-50.

2. Malignant Soft Tissue Tumors [Internet]. 2016 [cited 2016 Aug 21]. Available from: http://my. clevelandclinic.org/services/orthopaedics-rheumatology / disease-conditions/malignant-soft-tissue-tumors.

3. Hassawi BA, Suliman AY, Hasan IS. Soft tissue tumours - Histopathological study of 93 cases. Ann Coll Med Mosul. 2010;36(1\&2):92-8.

4. Rydholm A, Berg NO, Gullberg B et al. Epidemiology of soft tissue sarcoma in the locomotor system: A retrospective population based study of the inter-relationships between clinical and morphologic variables. ActaPathol Microbial Immunol Scand. 1984; 92: 363-74.

5. Vinod B Shidham, Donald a Hackbarth, Nora k Firsch et al. Benign and Malignant Soft Tissue Tumors. Medscape [Internet]. 2015[updated 2015 Aug 27; cited 2016 Oct 31]. Available from: http://emedicine. medscape.com/article/1253816-overview\#a7

6. Rosenberg AE. Bones, Joints and Soft Tissue Tumors. In: Kumar V, Abbas AK, Aster JC, editors.
Robbins Basic Pathology. 9th ed. Saunders: Elsevier Publishing; 2013.

7. Gustafson P. Soft tissue sarcoma. Epidemiology and prognosis in 508 patients. Acta Orthop Scand Suppl. 1994 Jun;259:1-31.

8. Krishnan Uni K. Grading of tumors. Chapter-1, Proceedings of the Fifth International CME and Update in Surgical Pathology. 2000; Hyderabad.

9. Rutkowski P, Lugowski I. Follow-up in soft tissue sarcomas. Magazine of Europian Medical Oncology. 2014;7(2):92-6.

10. Folpe AL, Gown AM. Immunohistochemistry for analysis of soft tissue tumors. Chapter-8 In: Weiss SW, Goldblum JR, editors. Enzinger and Weiss's Soft Tissue tumors. $4^{\text {th }}$ ed. St Louis: Mosby Publishing; 2001.

11. Fletcher C.D.M., Unni K.K., Mertens F. (Eds.): World Health Organization Classification of Tumors. Pathology and genetics of tumors of soft tissue and bone. IARC Press:Lyon 2002.

12. Coindre JM. Grading of soft tissue sarcomas: review and update. Arch Pathol Lab Med. 2006 Oct;130(10):1448-53.

13. Myhre-Jensen O. A consecutive 7-year series of 1331 benign soft tissue tumours. Clinicopathologic data. Comparison with sarcomas. Acta Orthop Scand. 1981 Jun;52(3):287-93.

14. Kransdorf MJ. Malignant soft-tissue tumors in a large referral population: distribution of diagnoses by age, sex, and location. AJR Am J Roentgenol. 1995 Jan;164(1):129-34.

\section{How to cite this article?}

Deepak MB, Suchitha S, Manjunath GV, Ira Bharadwaj. Clinico-histopathological analysis of malignant soft tissue tumors.Trop J Path Micro 2016;2(3):125-133.doi: 10.17511/jopm.2016.i03.08 